\title{
SIFAT ANATOMI DAN FISIS KAYU JATI DARI MUNA DAN KENDARI SELATAN
}

\author{
Anatomical and Physical Properties of Teak from Muna and \\ South-Kendari
}

\author{
Oleh/By: \\ Sri Rulliaty dan Mody Lempang
}

\begin{abstract}
It is traditionally acknowledged that teak wood (Tectona grandis L.f) originated from Muna district had a better quality than that of South-Kendari. The objective of this study was to evaluate the different characteristics of both teaks. Wood samples were collected from bottom, central and top part of trees from age class II and III (18 and 28 years) extracted from each region. Samples were then examined for their anatomical and physical characteristics to determine the quality.

Results revealed that teak wood samples from Muna had higher dimensions in fiber diameter, fiber lumen width and vessel diameter than those of South-Kendari samples. Such characteristics might bring the samples from Muna to have a higher specific gravity than the South-Kendari samples. It was also clearly shown that the older trees (age class III) possessed better characteristics than those of the young ones (age class II).
\end{abstract}

Keywords: Wood quality, teak, Muna, South-Kendari, specific gravity.

\section{ABSTRAK}

Secara tradisional masyarakat mengetahui bahwa kayu jati (Tectona grandis L.f) yang berasal dari Kabupaten Muna lebih baik daripada kayu sejenis yang berasal dari Kabupaten Kendari Selatan. Dalam penelitian ini dilakukan evaluasi terhadap perbedaan tersebut secara anatomis dan fisis. Contoh uji diambil dari bagian pangkal, tengah, dan ujung batang kayu jati dengan kelas unur II dan III (18 dan 28 tahun) masing-masing dengan 2 (dua) ulangan. Pengamatan dilakukan terhadap dimensi serat dan berat jenisnya.

Hasilnya menunjukkan bahwa contoh kayu yang berasal dari Kabupaten Muna memiliki dimensi serat yang lebih besar daripada contoh kayu dari Kendari Selatan. Tampak jelas dalam penelitian ini bahwa kayu dari pohon yang berumur lebih tua (kelas umur III) memiliki karakteristik yang lebih baik daripada kayu yang berasal dari pohon lebih muda (kelas umur II).

Kata kunci: Kualitas kayu, kayu jati, Muna, Kendari Selatan, berat jenis. 


\section{PENDAHULUAN}

Kayu masih menjadi bagian penting dalam pembuatan bangunan maupun kegunaan lainnya seperti barang kerajinan ataupun mebeler. Tetapi kayu yang mempunyai kualitas baik dan berasal dari tegakan yang masak tebang, saat ini sulit didapatkan dan semakin mahal harganya. Adanya perbedaan kualitas kayu sejenis yang berasal dari tempat yang berbeda juga menambah permasalahan yang dihadapi para pengguna kayu. Akibatnya para pengguna kayu sering merasa kecewa karena beberapa bangunan yang dihuni maupun barang kerajinan yang dikoleksi menjadi cepat rusak.

Kayu jati (Tectona grandis L.f.) merupakan salah satu tumbuhan penghara industri mebeler dan perahu phinisi. Di wilayah Indonesia bagian Timur banyak ditanam di propinsi Sulawesi Tenggara khususnya di kabupaten Kendari Selatan dan Muna. Masyarakat di daerah tersebut mempercayai bahwa kayu jati yamg berasal dari kabupaten Kendari Selatan mempunyai kualitas rendah dari kayu jati yang berasal dari kabupaten Muna, sehingga mereka enggan menggunakannya untuk berbagai keperluan primer seperti mebeler, kerangka dan daun pintu atau jendela, tiang rumah atau keperluan konstruksi lainnya.

Sehubungan dengan hal tersebut diatas, maka dilakukan penelitian ini yang bertujuan untuk mengetahui sifat anatomi dan fisik kayu jati yang berasal dari kedua daerah tersebut. Diharapkan hasil penelitian ini dapat mempertegas pemanfaatan kayu jati yang berasal dari kedua daerah tersebut.

\section{BAHAN DAN METODE}

\section{A. Lokasi Penelitian}

Pengambilan contoh kayu dilakukan di Ponggaluku, Kabupaten Kendari Selatan dan Tampo, Kabupaten Muna Utara. Secara geografis keduanya dipisahkan oleh selat yang memiliki kondisi lahan yang berbeda. Ponggaluku merupakan daerah berbukit dengan curah hujan lebih besar dari daerah Tampo yang tanahnya berkapur.

\section{B. Bahan dan Peralatan}

Contoh uji yang digunakan adalah 8 batang kayu jati yang berasal dari 2 lokasi yang berbeda dengan kelas umur pohon II dan III ( 18 dan 28 tahun), dengan diameter dan ketinggian bebas cabang yang hampir sama untuk masing-masing lokasi dan kelas umur pohon. Pohon tersebut dipilih secara acak. Bahan-bahan lain yang digunakan antara lain : alkohol teknis, ethanol, safranin, hidrogen peroksida, dan asam asetat glasial.

Peralatan yang digunakan diantaranya dial caliper, tabung reaksi, pisau mikrotom, dan mikroskop.

\section{Metode Penelitian}

Contoh uji diambil dari masing-masing pohon yang dibedakan atas 3 (tiga) tingkat ketinggian dalam batang yaitu pangkal, tengah, dan ujung. Pemotongan bagian pangkal diambil sekitar $5 \mathrm{~cm}$ dari bekas pemotongan batang bawah, bagian ujung sekitar $5 \mathrm{~cm}$ dari bagian bawah cabang pertama, bagian tengah merupakan bagian tengah antara bagian pangkal dan ujung. Dari masing-masing bagian diambil ketebalan $10 \mathrm{~cm}$ untuk pengamatan sifat anatomi. Pengamatan dilakukan terhadap dimensi serat, meliputi panjang, diameter, diameter lumen, dan tebal dinding serat. Sedangkan dimensi pembuluh meliputi panjang dan diameter. 
Untuk pengamatan serat dilakukan pembuatan preparat maserasi menggunakan larutan campuran $60 \%$ asam asetat glasial dengan $30 \%$ hidrogen peroksida dengan perbandingan volume 50 : 50 (Rulliaty, 1994).

Untuk pengamatan sifat fisik masing-masing batang pada bagian pangkal, tengah, dan ujung digergaji menjadi contoh uji berukuran $6 \times 6 \mathrm{~cm} \times$ panjang dolok. Untuk pengukuran kadar air segar kayu, pada setiap contoh uji dipotong ujungnya dengan panjang $5 \mathrm{~cm}$ dan langsung dibungkus dengan plastik di tempat penebangan sehingga kadar airnya tidak berkurang. Cara pengambilan, bentuk, dan dimensi contoh uji serta pengujian sifat fisik kayu dilakukan dengan metoda ASTM D 143-94 (ASTM, 1995)

Dalam penelitian ini digunakan rancangan percobaan petak terbagi dalam rancangan acak kelompok (Lantican, 1982; Gasperz, 1991). Selanjutnya bila hasil analisa sidik ragam berbeda nyata, dilanjutkan dengan uji beda nyata jujur (BNJ).

\section{HASIL DAN PEMBAHASAN}

Ringkasan sidik ragam parameter yang diamati dapat dilihat pada Tabel 1. Pada Tabel tersebut tampak bahwa lokasi tempat tumbuh memberikan pengaruh nyata terhadap diameter pembuluh dan sangat nyata masing-masing terhadap diameter serat, diameter lumen serat, dan berat jenis. Kelas umur memberikan pengaruh nyata terhadap panjang serat, dan sangat nyata terhadap berat jenis Sedangkan tingkat ketinggian dalam batang berpengaruh nyata terhadap nilai diameter serat dan diameter pembuluh. Interaksi antara tingkat ketinggian dalam batang dengan kelas umur berpengaruh nyata terhadap berat jenis. Sementara faktor-faktor lainnya tidak memberikan pengaruh yang nyata terhadap parameter yang diamati.

Tabel 1. Ringkasan analisa sidik ragam dimensi serat $(\mu)$, pembuluh $(\mu)$ dan berat jenis Table 1. Summary of the analysis of variance for fiber dimension $(\mu)$, vessel $(\mu)$, and specific gravity

\begin{tabular}{|l|c|c|c|c|c|c|c|c|}
\hline & & \multicolumn{6}{|c|}{ Nilai F Hitung (Computed F values) } \\
\cline { 2 - 8 } $\begin{array}{c}\text { Sumber variasi } \\
\text { (Source of } \\
\text { variation) }\end{array}$ & $\begin{array}{c}\mathrm{DB} \\
\text { (DF) }\end{array}$ & $\begin{array}{c}\text { Panjang } \\
\text { Serat } \\
\text { (Fiber length) }\end{array}$ & $\begin{array}{c}\text { Diameter } \\
\text { serat } \\
\text { (Fiber } \\
\text { diameter) }\end{array}$ & $\begin{array}{c}\text { Diameter } \\
\text { lumen } \\
\text { (Fiber } \\
\text { lumen } \\
\text { width) }\end{array}$ & $\begin{array}{c}\text { Tebal } \\
\text { dinding } \\
\text { serat } \\
\text { (Cell wall } \\
\text { thickness) }\end{array}$ & $\begin{array}{c}\text { Diameter } \\
\text { pembuluh } \\
\text { (Vessel } \\
\text { diameter) }\end{array}$ & $\begin{array}{c}\text { Panjang } \\
\text { pembuluh } \\
\text { (Vessel } \\
\text { length) }\end{array}$ & $\begin{array}{c}\text { Berat Jenis } \\
\text { (Specific } \\
\text { gravity) }\end{array}$ \\
\hline $\begin{array}{l}\text { Lokasi (L) } \\
\text { (Interaction) }\end{array}$ & 1 & $0,001 \mathrm{~ns}$ & $35,737^{* *}$ & $23,977 * *$ & $0,357 \mathrm{~ns}$ & $12,998^{*}$ & $0,230 \mathrm{~ns}$ & $42,436^{* *}$ \\
\hline $\begin{array}{l}\text { Kelas umur (U) } \\
\text { (Age class) }\end{array}$ & 1 & $10,366^{*}$ & $3,893 \mathrm{~ns}$ & $8,238 \mathrm{~ns}$ & $9,728 \mathrm{~ns}$ & $0,474 \mathrm{~ns}$ & $0,082 \mathrm{~ns}$ & $173,798^{* *}$ \\
\hline $\begin{array}{l}\text { Tingkat } \\
\text { ketinggian (T) } \\
\text { (Height level) }\end{array}$ & 2 & $2,064 \mathrm{~ns}$ & $76,385^{*}$ & $2,894 \mathrm{~ns}$ & $1,304 \mathrm{~ns}$ & $26,727 *$ & $0,533 \mathrm{~ns}$ & $3,445 \mathrm{~ns}$ \\
\hline $\begin{array}{l}\text { Interaksi TU } \\
\text { (Interaction) }\end{array}$ & 2 & $0,0004 \mathrm{~ns}$ & $0,265 \mathrm{~ns}$ & $0,306 \mathrm{~ns}$ & $0,082 \mathrm{~ns}$ & $0,527 \mathrm{~ns}$ & $2,618 \mathrm{~ns}$ & $5,535 *$ \\
\hline $\begin{array}{l}\text { Interaksi TL } \\
\text { (Interaction) }\end{array}$ & 2 & $0,00002 \mathrm{~ns}$ & $1,003 \mathrm{~ns}$ & $0,285 \mathrm{~ns}$ & $0,357 \mathrm{~ns}$ & $0,527 \mathrm{~ns}$ & $0,895 \mathrm{~ns}$ & $1,633 \mathrm{~ns}$ \\
\hline $\begin{array}{l}\text { Interaksi UL } \\
\text { (Interaction) }\end{array}$ & 1 & $0,004 \mathrm{~ns}$ & $0,292 \mathrm{~ns}$ & $0,146 \mathrm{~ns}$ & $0,004 \mathrm{~ns}$ & $1,308 \mathrm{~ns}$ & $2,879 \mathrm{~ns}$ & $4,084 \mathrm{~ns}$ \\
\hline $\begin{array}{l}\text { Interaksi TUL } \\
\text { (Interaction) }\end{array}$ & 2 & $0,00006 \mathrm{~ns}$ & $0,233 \mathrm{~ns}$ & $0,021 \mathrm{~ns}$ & $0,294 \mathrm{~ns}$ & $0,701 \mathrm{~ns}$ & $0,551 \mathrm{~ns}$ & $0,793 \mathrm{~ns}$ \\
\hline
\end{tabular}

Keterangan $\left(\right.$ Remarks): ${ }^{* *}=$ Sangat nyata $(\text { Highly significant })^{*}=$ Nyata $($ Significant $)$ ns $=$ Tidak nyata $($ Not significant) 
Menurut Panshin dan de Zeeuw (1980) ada korelasi antara dimensi sel dengan tingkat ketinggian dalam batang dan umur pohon. Umumnya dimensi sel bertambah sesuai dengan pertambahan umur pohon sampai periode tertentu dimana sel-sel kambium dewasa dan kemudian sel-sel yang terbentuk akan mempunyai dimensi sel yang lebih kecil dibandingkan dimensi sel yang dibentuk sebelumnya. Demikian pula lokasi tempat tumbuh dapat memberikan variasi terhadap dimensi sel yang terbentuk karena adanya pengaruh tempat tumbuh seperti kondisi tanah, cuaca atau iklim setempat yang berbeda (Tsoumis , 1969), hal ini juga dapat dilihat pada Tabel 2.

Tabel 2. Perbedaan berat jenis, diameter serat $(\mu)$, diameter lumen serat $(\mu)$, dan diameter pembuluh $(\mu)$ pada lokasi yang berbeda

Table 2 Differences of specific gravity, fiber diameter $(\mu)$, fiber lumen width ( $\mu)$, and vessel diameter $(\mu)$, at different location

\begin{tabular}{|l|c|c|}
\hline \multirow{2}{*}{$\begin{array}{c}\text { Parameter yang Diamati } \\
\text { (Parameter observation) }\end{array}$} & \multicolumn{2}{c|}{$\begin{array}{c}\text { Nilai Rata-rata pada Lokasi } \\
\text { (Mean values at different location) }\end{array}$} \\
\cline { 2 - 3 } & Kendari & Muna \\
\hline Berat Jenis (Specific gravity) & $0,63 \mathrm{~b}$ & $0,69 \mathrm{a}$ \\
\hline Diameter serat (Fiber diameter), mikron & $32,74 \mathrm{a}$ & $29,23 \mathrm{~b}$ \\
\hline Diameter lumen serat (Fiber lumen width), mikron & $23,62 \mathrm{a}$ & $20,27 \mathrm{~b}$ \\
\hline Diameter pembuluh (Vessel diameter), mikron & $197,26 \mathrm{a}$ & $168,42 \mathrm{~b}$ \\
\hline
\end{tabular}

Keterangan (Remark): Nilai rata-rata pada baris yang sama dan diikuti dengan huruf yang sama tidak berbeda nyata pada taraf $5 \%$ (Mean in row followed by a common letter are not significantly different at $5 \%$ level)

Dari hasil uji beda pada lokasi yang berbeda, tampak bahwa kayu jati yang berasal dari kabupaten Muna memiliki berat jenis yang lebih besar, akan tetapi diameter serat, diameter lumen serat dan diameter pembuluh yang lebih kecil. Hal ini erat kaitannya, karena diameter serat, diameter lumen serat, dan diameter pembuluh yang kecil menyebabkan elemen kayu yang tersusun menjadi rapat atau padat sehingga berat jenis nya lebih tinggi.

Perbedaan panjang serat dan berat jenis pada klas umur yang berbeda disajikan pada Tabel 3. Panjang serat kayu jati pada klas umur II berbeda nyata dengan panjang serat pada klas umur III. Demikian pula dengan berat jenis pada klas umur III lebih besar dan berbeda nyata dengan klas umur II. Panshin dan de Zeeuw (1980) menyebutkan bahwa dimensi sel akan bertambah nilainya sesuai dengan bertambahnya umur pohon sampai pada umur tertentu; dan ada variasi struktur anatomi yang dipengaruhi oleh perubahan umur kambium dan umur pohon.

Tabel 3. Perbedaan Panjang serat $(\mu)$ dan Berat Jenis pada Klas umur yang Berbeda Table 3. Differences of fiber length $(\mu)$, and specific gravity at different age class

\begin{tabular}{|l|c|c|}
\hline \multirow{2}{*}{$\begin{array}{c}\text { Parameter yang diamati } \\
\text { (Parameter observed) }\end{array}$} & \multicolumn{2}{|c|}{$\begin{array}{c}\text { Nilai rata-rata klas umur } \\
\text { (Mean value of age class) }\end{array}$} \\
\cline { 2 - 3 } & II & III \\
\hline Panjang serat (Fiber length), mikron & $1188,853 \mathrm{~b}$ & $1303,773 \mathrm{a}$ \\
\hline Berat jenis (Specific gravity) & $0,63 \mathrm{~b}$ & $0,69 \mathrm{a}$ \\
\hline
\end{tabular}

Keterangan (Remark): Nilai rata-rata pada baris yang sama dan diikuti dengan huruf yang sama tidak berbeda nyata pada taraf $5 \%$ (Mean in row followed by a common letter are not significantly different at $5 \%$ level)

Untuk perbedaan pada tingkat ketinggian dalam batang disajikan pada Tabel 4. Pada Tabel tersebut tampak bahwa diameter lumen serat pada bagian pangkal batang lebih besar 
dari pada bagian tengah dan ujung batang, dan berbeda nyata dengan bagian tengah dan ujung batang. Diameter lumen serat pada pohon jati semakin ke bagian ujung semakin kecil nilainya, hal ini sesuai pula dengan diameter seratnya (pangkal 26,32 mikron, tengah 25,92 mikron, dan ujung 25,58 mikron), meskipun tidak berbeda nyata. Berbeda dengan tebal dinding serat yang mempunyai nilai rata-rata makin besar ke bagian ujung batang (pangkal 3,46 mikron, tengah 3,69 mikron, dan ujung 3,88 mikron ).

Tabel 4. Perbedaan diameter lumen serat $(\mu)$ dan diameter pembuluh $(\mu)$ pada tingkat ketinggian dalam batang

Table 4. Differences of fiber lumen width $(\mu)$, and vessel diameter $(\mu)$ at different part of trunk

\begin{tabular}{|l|c|c|c|}
\hline \multirow{2}{*}{$\begin{array}{c}\text { Parameter yang diamati } \\
\text { (Parameter observed) }\end{array}$} & \multicolumn{3}{|c|}{$\begin{array}{c}\text { Nilai rata-rata }(\mu) \text { pada tingkat ketinggian dalam batang } \\
\text { (Mean values at different height level) }\end{array}$} \\
\cline { 2 - 4 } & Pangkal (Bottom) & Tengah (Central) & Ujung (Top) \\
\hline $\begin{array}{l}\text { Diameter lumen serat } \\
\text { (Fiber lumen width) }\end{array}$ & $15,13 \mathrm{a}$ & $14,59 \mathrm{~b}$ & $14,16 \mathrm{c}$ \\
\hline $\begin{array}{l}\text { Diameter pembuluh } \\
\text { (Vessel diameter) }\end{array}$ & $110,14 \mathrm{c}$ & $123,00 \mathrm{~b}$ & $132,54 \mathrm{a}$ \\
\hline
\end{tabular}

Keterangan (Remarks): Nilai rata-rata pada baris yang sama diikuti dengan huruf yang sama tidak berbeda nyata pada taraf $5 \%$ (Mean in row followed by a common letter are not significantly different at $5 \%$ level)

Diameter pembuluh berbeda nyata antara bagian pangkal, tengah, dan ujung. Pada bagian pangkal batang diameter pembuluh (110,14 mikron) lebih kecil dibandingkan dengan bagian tengah (123,00 mikron), dan ujung batang (123,54 mikron). Dengan demikian semakin kearah ujung batang diameter pembuluh semakin besar, hal ini merupakan kebalikan dari diameter lumen. Pada bagian pangkal batang umumnya mempunyai kerapatan dan berat jenis yang lebih besar dari pada bagian ujung, karena bagian pangkal lebih dulu dibentuk. Pada waktu pembentukan pangkal batang, bagian tajuk pohon belum sebanyak pada waktu pembentukan bagian ujung batang, sehingga unsur hara yang diproses serta hormon pertumbuhan yang berpengaruh terhadap dimensi sel juga kurang, akibatnya dimensi sel yang terbentuk lebih kecil dan rapat (Panshin dan de Zeeuw, 1980)

Pada interaksi tingkat ketinggian dalam batang dengan kelas umur menunjukkan pengaruh yang nyata terhadap berat jenis (Tabel 5). Nilai rata-rata berat jenis pada bagian pangkal lebih besar bila dibandingkan dengan bagian tengah dan ujung batang, demikian pula nilai rata-rata berat jenis lebih besar pada klas umur III. Umumnya rata-rata berat jenis berbeda yaitu pada interaksi antara tingkat ketinggian dalam batang dan kelas umur.

Tabel 5. Perbedaan berat jenis pada interaksi tingkat ketinggian dalam batang dengan kelas umur

Table5. Defferences of specific gravity at interaction between height level and age class

\begin{tabular}{|c|c|c|c|}
\hline \multirow{2}{*}{$\begin{array}{c}\text { Nilai rata-rata kelas umur } \\
\text { (Mean value of age class) }\end{array}$} & \multicolumn{3}{|c|}{$\begin{array}{c}\text { Nilai rata rata tingkat ketinggian dalam batang } \\
\text { (Mean values at different height level) }\end{array}$} \\
\cline { 2 - 4 } & Pangkal (Bottom) & Tengah (Central) & Ujung (Top) \\
\hline II & $0,654 \mathrm{~d}$ & $0,610 \mathrm{f}$ & $0,625 \mathrm{e}$ \\
\hline III & $0,692 \mathrm{a}$ & $0,683 \mathrm{c}$ & $0,692 \mathrm{~b}$ \\
\hline
\end{tabular}

Keterangan (Remarks) : Nilai rata-rata yang diikuti dengan huruf yang sama tidak berbeda nyata pada taraf $5 \%$ (Mean in row followed by a common letter are not significantly different at $5 \%$ level) 
Seperti kita ketahui bahwa berat jenis berhubungan dengan kekuatan kayu. Pada umumnya semakin besar nilai berat jenis kayu yang terbentuk maka kayu akan semakin kuat. Akan tetapi perbedaan berat jenis kayu yang berasal dari kedua lokasi yang berbeda ini hanya sekitar 0,06 dan berdasarkan Tabel kelas kuat kayu (Seng, 1990) disebutkan bahwa kayu dengan berat jenis 0,60-0,90 termasuk dalam kategori kelas kuat II, dengan keteguhan lengkung mutlak $725-1100$ (in) $\mathrm{kg} / \mathrm{cm}^{2}$, dan keteguhan tekan mutlak $425-650$ (in) $\mathrm{kg} / \mathrm{cm}^{2}$. Dengan demikian maka kayu jati yang berasal dari kedua lokasi yang berbeda ini meskipun memiliki berat jenis yang berbeda nyata akan tetapi berada pada penggolongan kelas kuat yang sama. Maka kayu jati yang berasal dari kabupaten Kendari dan memiliki berat jenis lebih rendah dapat digunakan untuk keperluan yang sama dengan kayu jati yang berasal dari kabupaten Muna, baik untuk mebeler maupun konstruksi.

Secara visual warna kayu jati yang berasal dari kedua lokasi tersebut setelah kering memiliki warna hampir sama yaitu berkisar antara coklat muda sampai coklat tua, tidak ada perbedaan warna yang mencolok. Perbedaan diameter batang kayunya disajikan pada Tabel 6.

Tabel 6. Diameter batang kayu yang diamati dan prosentase kayunya . Table 6. Percentage and stem diameter of wood observed

\begin{tabular}{|l|c|c|c|c|}
\hline \multirow{2}{*}{\begin{tabular}{c}
\multirow{2}{*}{$\begin{array}{c}\text { Diameter yang diamati } \\
\text { (Diameter observed) }\end{array}$} \\
\cline { 2 - 5 }
\end{tabular}} & \multicolumn{4}{|c|}{$\begin{array}{c}\text { Kelas Umur dan Lokasi Asal Kayu } \\
\text { (Age class and location) }\end{array}$} \\
\cline { 2 - 5 } & Kendari & Muna & Kendari & Muna \\
\hline $\begin{array}{l}\text { Diameter batang (Stem diameter), } \\
\mathrm{cm}\end{array}$ & 30,63 & 26,40 & 37,78 & 28,28 \\
\hline $\begin{array}{l}\text { Diameter kayu teras (Heartwoodd } \\
\text { diameter), cm }\end{array}$ & 21,50 & 17,60 & 30,37 & 21,67 \\
\hline $\begin{array}{l}\text { Prosentase kayu teras } \\
\text { (Percentage of heartwood part), } \\
\%\end{array}$ & 49,27 & 44,44 & 66,16 & 58,43 \\
\hline $\begin{array}{l}\text { Prosentase kayu gubal } \\
\text { (Percentage of sapwood part), \% }\end{array}$ & 50,73 & 55,56 & 33,84 & 45,17 \\
\hline
\end{tabular}

Kayu yang berasal dari Kendari memiliki diameter batang, kayu teras dan prosentase yang lebih besar, baik pada klas umur II maupun III dibandingkan kayu jati yang berasal dari kabupaten Muna. Pengaruh kondisi lingkungan dapat menjadi salah satu penyebabnya, dimana kabupaten Kendari Selatan merupakan daerah yang cukup subur, sehingga kayu jati yang berasal dari daerah tersebut memiliki diameter batang dan teras yang lebih besar meskipun dengan berat jenis yang lebih rendah.

\section{KESIMPULAN DAN SARAN}

Umur pohon dan lokasi tempat tumbuh berpengaruh terhadap dimensi serat, maupun pembuluh, serta berat jenis kayu jati. Panjang serat dan berat jenis kayu jati akan semakin besar pada umur pohon yang lebih tua. Panjang serat pada klas umur II (1188,853 mikron) lebih kecil daripada panjang serat pada kelas umur III (1.303,7 mikron), dan berat jenis kayu pada kelas umur II $(0,63)$ lebih kecil daripada berat jenis pada kelas umur III $(0,69)$.

Diameter serat (32,74 mikron), lumen serat (23,62 mikron), dan pembuluh (197,26 mikron) kayu jati yang berasal dari Kendari Selatan lebih besar dari diameter serat $(29,23$ mikron), lumen serat ( 20,27 mikron), dan pembuluh (168,42 mikron) kayu jati dari Muna. 
Berat jenis kayu jati yang berasal dari Kendari $(0,63)$ lebih rendah 0,06 dibandingkan dengan berat jenis kayu jati yang berasal dari Muna $(0,69)$. Meskipun demikian keduanya ada dalam kategori kelas kuat yang sama yaitu kelas kuat II. Dengan demikian dimungkinkan keduanya dapat dipakai dalam penggunaan yang sama baik sebagai bahan baku mebeler maupun konstruksi.

Diharapkan ada penelitian lanjutan untuk sifat pemesinan dan keawetannya, jenis serta kadar zat ekstraktif yang dikandungnya, karena untuk mebel, kusen dan jendela persyaratan keawetan sangat diperlukan

\section{DAFTAR PUSTAKA}

ASTM. 1995. Annual Book of ASTM Standards 22. American Society for Testing and Materials. Philadelphia. USA.

Gasperz, V. 1994. Metoda perancangan percobaan. CV Armico. Bandung.

Lantican, C.B. 1982. Manual of statistical procedures for forestry research. Part I and II, pp 23 - 27. UPLB. Los Baños, Philippines.

Panshin, A.J. dan C. de Zeeuw. 1980. Textbook of Wood Technology. $14^{\text {th }}$ Ed. McGrawHill Book Co. New York.

Rulliaty, S. 1994. Wood quality indicators as estimator of juvenile wood in Mahogany (Swietenia macrophylla King) from forest plantation in Sukabumi, West Java, Indonesia. Thesis Master. UPLB, Los Banos, Phillipina. Tidak dipublikasikan.

Seng, O. D. 1990. Berat jenis dari jenis-jenis kayu Indonesia dan pengertian beratnya kayu untuk keperluan praktek. Pengumuman Nr. 13. Pusat Penelitian dan Pengembangan Hasil Hutan. Bogor.

Tsoumis, G. 1969. Wood As Raw Material: Source, Structure, Chemical, Composition, Growth, Degradation and Identification. Pergamon Press, Oxford, London. 